\title{
A COMPARISON OF THE ROSE-WAALER, LATEX FIXATION, "RA-TEST," AND BENTONITE FLOCCULATION TESTS
}

\author{
BY \\ C. L. GREENBURY \\ With the Technical Assistance of J. KENINGale \\ From the Pathology Laboratory, Stoke Mandeville Hospital, Aylesbury
}

(RECEIVED_FoR PUBLICATION MAY 16, 1960)

\begin{abstract}
The bentonite flocculation test of Bozicevich, Bunim, Freund, and Ward (1958), the latex fixation test of Singer and Plotz (1956), and the " RA-test" (a latex reagent for use as a slide test) of Hyland Laboratories have been compared with each other and with a modified Rose-Waaler test, the behaviour of which has been previously extensively investigated. In these tests sera from 2,250 patients were tested by two or more methods on 3,000 occasions. The findings of this trial are set out and the merits of the tests and reasons for disagreement among them are discussed. It is concluded that the most satisfactory means of testing rheumatoid sera is by the Rose-Waaler test and the "RA-test," or a satisfactory modification of it, in parallel.
\end{abstract}

The presence in the serum of most patients suffering from rheumatoid arthritis of a substance capable of agglutinating red cells sensitized with homologous rabbit antibody, and of combining with Cohn fraction II ( $\gamma$-globulin), is well established. This substance, now generally known as rheumatoid factor, is a high molecular weight globulin which in serum is found in combination with, and separable from, smaller $\gamma$-globulin molecules (Franklin, Holman, Müller-Eberhard, and Kunkel, 1957).

The rheumatoid factor occurs in a high proportion of rheumatoid sera and, with the exception of the " collagen diseases," in very few other conditions ; consequently laboratory tests for its presence are becoming increasingly used as an aid to diagnosis and prognosis. Chief among the tests now in use are the sensitized sheep cell (Rose-Waaler) test in its many modifications; a variety of tests relying on the aggregation of latex particles by rheumatoid factor in the presence of fraction II, and the bentonite flocculation test (Bozicevich et al., 1958) consisting of the agglutination of particles of bentonite pretreated with fraction II and dyed with methylene blue. There are many other methods of demonstrating the rheumatoid factor, for some of which great sensitivity has been claimed, notably tests using the euglobulin fraction rather than whole serum and the demonstration of an absence of an inhibitor of the Rose-Waaler test in rheumatoid sera; these tests, however, together with several others, are not widely used.
During the past six years we have conducted, with Dr. A. G. S. Hill, Director of the Oxford Regional Rheumatism Research Unit, and others, an investigation into the clinical significance of the Rose-Waaler test in a large series of patients, including 500 cases of rheumatoid arthritis. We have also performed many tests for other clinicians in this and other hospitals. With this experience as a basis it seemed helpful to compare other readily available tests in parallel with the Rose-Waaler test. The tests chosen for the comparison were the latex fixation test of Singer and Plotz (1956), the "RA-test," which is a commercially produced latex reagent for use as a slide test, and the bentonite flocculation test (Bozicevich et al., 1958), since it seemed that these were the most suitable for routine laboratory use. The findings in a comparative series are presented here.

\section{Clinical Material}

Sera from 2,250 patients have been tested on more than 3,000 occasions. The patients from whom the sera were derived fall into two groups: those from the Rheumatism Research Centre (900) and those from all other sources $(1,350)$. In the former group the diagnosis available has been the best possible, being arrived at after careful and repeated examinations and modified as necessary. The diagnosis used in compiling the data for the present survey has been that arrived at at the most recent assessment. In the latter group, the only diagnosis avail- 
able has been that given on the laboratory request form received with the specimen.

\section{Diagnostic Criteria}

Patients from the Rheumatism Research Centre have been classified in respect of rheumatoid arthritis by criteria slightly modified from those of the American Rheumatism Association. It should be noted that a diagnosis of rheumatoid arthritis by these criteria does not imply that the case is either severe or long-standing, and indeed many cases in this series have minimal clinical signs and have been tested within a few weeks of the onset of the disease.

\section{Laboratory Materials and Methods}

Sheep Cell Agglutination (Rose-Waaler) Test.-The method was that described by Greenbury (1957). The test is done in perspex agglutination trays. After inactivation for $20 \mathrm{~min}$. at $56^{\circ} \mathrm{C}$. sera are diluted in saline containing $2.5 \%$ sheep serum in two-fold steps from 1 in 2 to 1 in 1,024 . Two series of dilutions of each serum are made; to each dilution of one series is added an equal volume of $1 \%$ sheep cells sensitized with rabbit antisheep cell serum, and to the other (control) series a volume of $1 \%$ unsensitized cells. The trays are incubated at $37^{\circ} \mathrm{C}$. for one hour and are then kept at $4^{\circ} \mathrm{C}$. overnight. Readings are made next day by observing the pattern of sedimented cells on the bottom of the cups. The test is regarded as positive if the serum, absorbed if necessary, agglutinates sensitized cells at a dilution of 1 in 16; however, the great majority $(96 \%)$ of positive sera have titres higher than 1 in 32 .

The essential feature of this method is the application of the highest possible dose of rabbit anti-sheep cell serum for sensitizing the sheep cells. This considerably increases the sensitivity of the test without any loss of specificity. In the preliminary titration of the rabbit antiserum the dilutions are separated by a factor of only $\sqrt{ } 2$, in order to determine as accurately as possible the highest concentration of antiserum which can be used without causing agglutination of the red cells. Rabbit antiserum at this concentration is added to an equal volume of a $2 \%$ suspension of sheep cells, the resulting mixture being the $1 \%$ sensitized cells used in the test.

Latex Fixation Test.-The method used was that of Singer and Plotz (1956). To dilutions in buffer of the serum under test is added an equal volume of a buffered suspension of uniform latex particles, containing $0.04 \%$ fraction II ( $\gamma$-globulin). After two hours at $56^{\circ} \mathrm{C}$. the tubes are centrifuged and inspected for aggregation of the latex particles. In the present series, however, sera were tested only at a single dilution, 1 in 20 . It was found that the best results were obtained if, after centrifuging, the deposits were resuspended and the tubes centrifuged a second time. This did not materially increase the number of unexpected positives and made reading considerably easier. Results range from a complete negative, the latex particles remaining evenly suspended and any precipitate being easily resuspended, to complete aggregation of the particles with a crystalclear supernatant.

Bentonite Test.-This was a modification of the method described by Bunim and his colleagues (Bozicevich et al., 1958) which in outline is as follows.

A suspension of bentonite particles of a suitable size range is obtained by differential centrifugation and to it is added $1 \%$ fraction II in buffer. After $15 \mathrm{~min}$. the fraction-II-coated particles are washed and a small quantity of methylene blue is added. After rewashing, the now deep blue particles are suspended in phosphate buffer and a small quantity of Tween 80 is added. In the original method one drop of sensitized bentonite suspension was added to drops of a serial dilution of the serum to be tested on a large microscope slide. The slide was then placed on a rotating machine and inspected for agglutination after $20 \mathrm{~min}$. In the present series only one dilution ( 1 in 20) of the serum was tested. The tests were done on the platforms $(1 \mathrm{in} . \times 0.3 \mathrm{in}$.) of a grooved slide (Murray, 1944). The slides were placed in a tray which was rocked by hand for 20 min., or until agglutination of the particles in negative controls became imminent, whichever was the shorter period.

Hyland " RA-test."-This is a commercially produced latex/fraction II reagent for use as a slide test. The reagent is a milky suspension dyed pale green. The makers recommend that one drop each of the reagent and $a 1$ in 20 dilution in glycine buffer of the serum under test be mixed on a glass slide, which is then rocked back and forth. The results are read after $1 \mathrm{~min}$. The results vary from no change to complete aggregation of the particles. Tests were done on grooved slides as described under the bentonite test. Any degree of unmistakable aggregation has been taken as positive. The best results were obtained if readings were made after $3 \mathrm{~min}$. instead of $1 \mathrm{~min}$. as recommended by the manufacturers, although strongly positive sera produce marked aggregation with complete clearing of the surrounding fluid within a few seconds.

Slide Latex Reagent (see Discussion).-This is made up as follows:

(1) Polysterene Latex Particles.-Diluted to form stock suspension (Singer and Plotz, 1956), this is about $1 \%$ solids.

(2) Glycine Buffer.-0.1 M Glycine in $1 \% \mathrm{NaCl}$ adjusted to $p \mathrm{H} \mathrm{8.2.}$

(3) $0.5 \% \gamma$-Globulin in glycine buffer.

(4) Masson's light green.

Preparation.-To $3 \mathrm{ml}$. buffer add $0.2 \mathrm{ml}$. of $0.5 \%$ 仙 $\gamma$-globulin solution. Heat at $60^{\circ} \mathrm{C}$. for $3 \mathrm{~min}$. Cool and add $2 \mathrm{ml}$. latex particle suspension and 1 drop Masson's 0 light green. This reagent has been used in the same way $\mathbb{D}$ as " RA-test" reagent.

\section{Results}

All sera were submitted to the Rose-Waaler test $\frac{\vec{D}}{\mathbb{O}}$ and all but a few to the latex fixation test. On about $\stackrel{\mathbb{Q}}{\mathbb{Q}}$ the first 2,400 specimens the bentonite test also was $\stackrel{\mathbb{Q}}{\Omega}$ used, after which, and for the rest of the series, the "RA-test" was included; after a further 300 specimens the bentonite test was dropped. 
In all, sera from 2,250 patients were tested on 3,250 occasions with two or more tests. The majority of patients were tested only once, although many, especially those with rheumatoid arthritis, were tested on several separate occasions.

In order to provide a firm basis for the comparisons with the Rose-Waaler test which follow, a summary of our previous experience of the accuracy of our modification of this test is given in Table I. (These figures refer to a series investigated in great detail with Dr. A. G. S. Hill, Director of the Oxford Regional Rheumatism Research Centre, and other colleagues, to be published.)

TABLE I

RESULTS WITH MODIFIED ROSE-WAALER TEST

\begin{tabular}{|c|c|c|c|}
\hline \multirow{2}{*}{ Diagnosis } & & \multicolumn{2}{|c|}{$\begin{array}{l}\text { Rose-Waaler } \\
\text { Results }\end{array}$} \\
\hline & & + & - \\
\hline $\begin{array}{l}\text { Rheumatoid } \\
\text { arthritis }\end{array}$ & 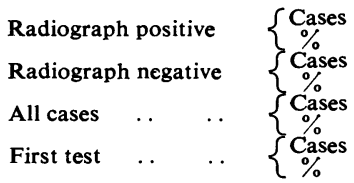 & $\begin{array}{l}336 \\
91 \\
101 \\
77 \cdot 1 \\
437 \\
87 \cdot 4 \\
410 \\
83 \cdot 8\end{array}$ & $\begin{array}{l}33 \\
9 \\
30 \\
22 \cdot 9 \\
63 \\
12 \cdot 6 \\
79 \\
16 \cdot 2\end{array}$ \\
\hline $\begin{array}{l}\text { Not } \\
\text { rheumatoid } \\
\text { arthritis }\end{array}$ & $\underset{\%}{\text { Cases }}$ & 11 & $\begin{array}{l}373 \\
97 \cdot 1\end{array}$ \\
\hline
\end{tabular}

In the first three rows in Table I a patient has been scored positive if he has been sero-positive on any single occasion during the period of observation. That is to say, about $10 \%$ of rheumatoid patients whose results in the Rose-Waaler test fluctuate from time to time have been scored positive. In order to keep the issue as clear as possible, cases of " possible" and "probable" rheumatoid arthritis, also psoriatic arthropathy, "collagen diseases," and generalized osteoarthritis, which may mask or be confused with rheumatoid arthritis, have been omitted from this table.
The results show this modification of the RoseWaaler test to give a very high positive rate in rheumatoid arthritis and a low proportion of what may be false positives. It therefore forms a suitable base with which to compare the efficiency of other tests.

Table II compares the results obtained with all pairs of tests, including repeats on the same patient. In compiling this table tests giving equivocal or atypical results have been omitted. They are as follows: Rose-Waaler $25(0.78 \%$ of all tests $)$, tube latex $88(2.6 \%)$, bentonite $50(1.7 \%)$, " RA-test " 15 $(1.8 \%)$.

In all pairings the agreement is in the region of $90 \%$. This, however, is a slightly unflattering figure since there was a tendency to repeat tests more frequently on patients with whose sera the tests gave discordant results.

The results obtained with each of the tests related to a diagnosis of rheumatoid arthritis and to the source of the patient are given in Table III. These figures refer to a single test on each patient. In order to minimize any advantage there might be in favour of the Rose-Waaler test due to our longer experience with it, the results chosen for inclusion in Table III have been those of the latest test on each patient. Cases of "possible" and "probable" rheumatoid arthritis have been classified as "not rheumatoid arthritis": this accounts for the high incidence of positive results in this group.

The proportion of positive Rose-Waaler results in the rheumatoid arthritis group from the Rheumatism Research Unit agrees well with those recorded in Table I. (There is in fact some overlap in the material from which these tables are compiled.) Note the lower proportion of positive results in rheumatoid arthritis patients coming from sources other than the Rheumatism Research Unit.

Since the margin of disagreement between the tests is small a further comparison between pairs of tests is given in Table IV.

TABLE II

COMPARISON OF TESTS BY PAIRS

\begin{tabular}{|c|c|c|c|c|c|c|c|c|c|c|}
\hline & & & & & $+^{(a)^{*}}+$ & $-^{(b)}-$ & $++^{(c)}-$ & $-^{\text {(d) }}+$ & $\begin{array}{l}\text { Agreements } \\
\text { (a) }+ \text { (b) }\end{array}$ & $\begin{array}{l}\text { Total } \\
\text { Tests }\end{array}$ \\
\hline Rose-Waaler compared with latex test & $\cdots$ & . & $\cdots$ & Tests & 1,156 & 1,737 & 185 & 144 & $\begin{array}{l}2,893 \\
89 \cdot 8\end{array}$ & 3,222 \\
\hline Rose-Waaler compared with bentonite $t$ & test & . & . & & $\begin{array}{l}964 \\
35.4\end{array}$ & 1,511 & $\begin{array}{c}170 \\
6 \cdot 2\end{array}$ & $\begin{array}{l}80 \\
2 \cdot 9\end{array}$ & $\begin{array}{r}2,475 \\
90.9\end{array}$ & 2,725 \\
\hline Rose-Waaler compared with " RA-test" & & . & $\ldots$ & Tests & $\begin{array}{l}326 \\
40 \cdot 4\end{array}$ & $\begin{array}{l}408 \\
50 \cdot 6\end{array}$ & $\begin{array}{l}35 \\
4 \cdot 3\end{array}$ & 35 & $\begin{array}{r}734 \\
91\end{array}$ & 808 \\
\hline Latex compared with bentonite test & . & . & .. & Tests & $\begin{array}{r}917 \\
34 \cdot 7\end{array}$ & $\begin{array}{c}1,498 \\
56 \cdot 7\end{array}$ & 126 & 101 & 2,515 & 2,642 \\
\hline Latex compared with " RA-test" & . & . & . & Tests & $\begin{array}{l}333 \\
41 \cdot 7\end{array}$ & $\begin{array}{r}392 \\
49 \cdot 1\end{array}$ & $\begin{array}{l}44 \\
5 \cdot 5\end{array}$ & 30 & $\begin{array}{l}725 \\
90 \cdot 8\end{array}$ & 799 \\
\hline Bentonite compared with " RA-test" & . & $\cdots$ & .. & Tests & $\begin{array}{c}141 \\
46 \cdot 2\end{array}$ & $\begin{array}{r}138 \\
45 \cdot 3\end{array}$ & $\begin{array}{l}3 \\
1\end{array}$ & $\begin{array}{l}23 \\
7 \cdot 5\end{array}$ & $\begin{array}{c}279 \\
91 \cdot 5\end{array}$ & 305 \\
\hline
\end{tabular}

* The two signs in each column refer respectively, in order, to the results of each of the pairs of tests named in the first column. 
TABLE III

TEST RESULTS RELATED TO DIAGNOSIS OF RHEUMATOID ARTHRITIS

\begin{tabular}{|c|c|c|c|c|c|c|c|c|c|c|}
\hline \multirow{3}{*}{ Source } & \multirow{3}{*}{ Diagnosis } & & \multicolumn{7}{|c|}{ Results of Tests } & \\
\hline & & & \multicolumn{2}{|c|}{ Rose-Waaler } & \multicolumn{2}{|c|}{ Bentonite } & \multicolumn{2}{|c|}{ Latex } & \multicolumn{2}{|c|}{ "RA-test" $\overline{\underline{O}}$} \\
\hline & & & + & - & + & - & + & - & + & $-\frac{\bar{\omega}}{\bar{\Phi}}$ \\
\hline \multirow{2}{*}{$\begin{array}{l}\text { Rheumatism } \\
\text { Research } \\
\text { Unit }\end{array}$} & Rheumatoid arthritis & $\underset{\%}{\text { Cases }}$ & $\begin{array}{c}350 \\
82 \cdot 3\end{array}$ & $\begin{array}{l}75 \\
17 \cdot 7\end{array}$ & $\begin{array}{c}305 \\
80.7 \\
\end{array}$ & $\begin{array}{l}73 \\
19 \cdot 3\end{array}$ & $\begin{array}{c}338 \\
82 \cdot 2\end{array}$ & $\begin{array}{l}73 \\
17.8\end{array}$ & $\begin{array}{c}146 \\
83.9\end{array}$ & 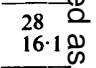 \\
\hline & Not rheumatoid arthritis* & $\begin{array}{c}\text { Cases } \\
\%\end{array}$ & $\begin{array}{l}52 \\
11.5 \\
\end{array}$ & $\begin{array}{c}402 \\
88.5 \\
\end{array}$ & $\begin{array}{l}42 \\
10 \cdot 3 \\
\end{array}$ & $\begin{array}{c}67 \\
89.7 \\
\end{array}$ & $\begin{array}{c}44 \\
9.9 \\
\end{array}$ & $\begin{array}{c}400 \\
90 \cdot 1 \\
\end{array}$ & $\begin{array}{l}20 \\
14.8 \\
\end{array}$ & $\begin{array}{r}115 . \\
85.2\end{array}$ \\
\hline \multirow[b]{2}{*}{ Others } & Rheumatoid arthritis & $\underset{\%}{\text { Cases }}$ & $\begin{array}{r}222 \\
72 \cdot 5 \\
\end{array}$ & $\begin{array}{l}84 \\
27 \cdot 5 \\
\end{array}$ & $\begin{array}{c}168 \\
72 \cdot 7 \\
\end{array}$ & $\begin{array}{l}63 \\
27 \cdot 3 \\
\end{array}$ & $\begin{array}{r}2 \cdot 7 \\
75 \cdot 6 \\
\end{array}$ & $\begin{array}{l}70 \\
24 \cdot 4 \\
\end{array}$ & $\begin{array}{l}81 \\
70 \cdot 4 \\
\end{array}$ & $29 \cdot 6 \vec{\omega}$ \\
\hline & Not rheumatoid arthritis* & $\underset{\%}{\text { Cases }}$ & $\begin{array}{c}115 \\
11 \cdot 1\end{array}$ & $\overline{922}$ & $\begin{array}{l}85 \\
10 \cdot 3\end{array}$ & $\begin{array}{c}740 \\
89.7\end{array}$ & $\begin{array}{c}134 \\
13.4\end{array}$ & $\overline{867}$ & $\begin{array}{l}47 \\
17\end{array}$ & 229 웅 \\
\hline
\end{tabular}

* Not rheumatoid arthritis in this table includes patients diagnosed as " possible" and "probable" rheumatoid arthritis. This accounts for $A$ the high percentage of positives in this group.

In this table, in order to obtain the greatest accuracy, results on patients from the Rheumatism Research Unit have been used for all comparisons except those involving the "RA-test," for which the rather smaller numbers have made it necessary to include patients from all sources. The "likelihood ratios," values of which are given in Table IV, provide an index of the reliability of the relevant result in the diagnosis of rheumatoid arthritis. The likelihood ratio for a particular type of result is defined as:

Probability of this result in patients with rheumatoid arthritis Probability of this result in patients without rheumatoid arthritis

In the absence of any other relevant knowledge about the patient the likelihood ratio expresses the odds in favour of rheumatoid arthritis for a patient showing this particular result. The more efficient a test, or combination of tests, the higher the likelihood ratio for a positive result and the lower the ratio for a negative result. In interpreting Table IV it must be noted that comparisons can only be made between figures in the same column, comparisons between figures in different columns not being valid. Consideration of the figures shows some superiority of the Rose-Waaler over both the bentonite and latex tests. The "RA-test" came out of the comparison a little better than the Rose-Waaler test. Bentonite/ "RA-test" comparisons were too few to be worth recording in Table IV.
It can be seen from Table IV that for any pair of tests the result when the tests are in agreement is more reliable than the result of either of the tests singly, i.e., the likelihood ratios for double positives and negatives are respectively higher and lower than for either of the individual members of the pair.

In the great majority of instances in which the Rose-Waaler test was positive in the presence of aO negative result with one or more of the other tests, s the Rose-Waaler titre of the serum was low. The modal titre of all positive sheep cell tests was noto less than 1,024, whereas the modal titre in cases giving discordant results was 256 . This applied to false as well as true positive Rose-Waaler results. .3 Conversely it was usual, though not invariable, for the positive results to be weak in the latex, bentonite? or "RA-test" in sera which gave a negative result흐 in the Rose-Waaler test.

The Rose-Waaler test very occasionally shows a을 prozone effect, the agglutination being weaker, but never absent, in the lower than in the higher serum? dilutions. It seemed possible therefore that, since only a single low serum dilution was being used for the factor II group of tests, prozoning in these test might be responsible in some instances for unexplained negative results. Accordingly a consider $-\tilde{O}$ able number of sera giving unexpectedly negative or weak results in the latex test were fully titrated out with latex. Although in a very few sera the particle

TABLE IV

LIKELIHOOD RATIOS IN FAVOUR OF A DIAGNOSIS OF RHEUMATOID ARTHRITIS

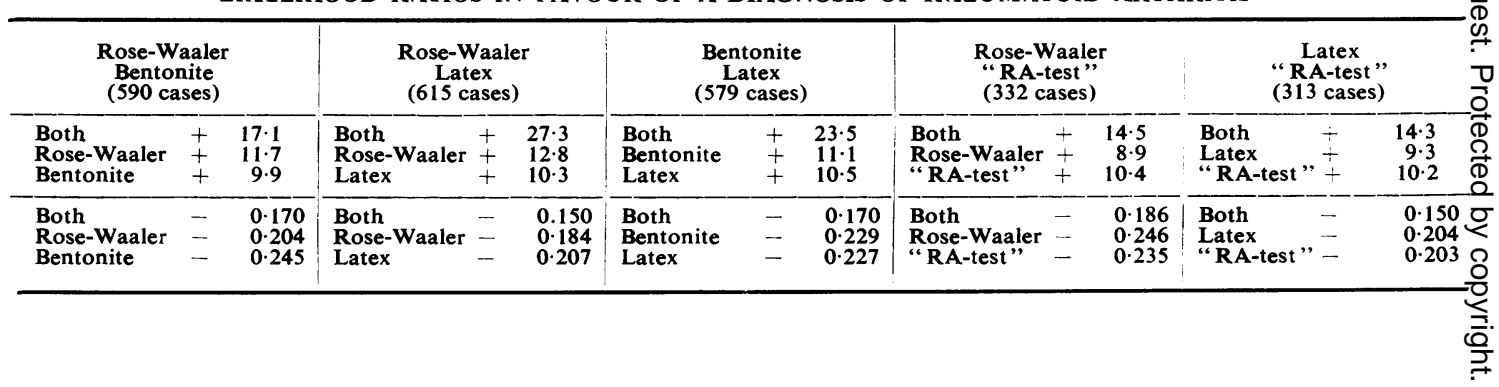


aggregation was more marked in higher serum dilution, in no instance was a positive result obtained at a higher dilution in the presence of a negative result at 1 in 20. It therefore seems that prozoning cannot explain a false negative reaction with the latex test.

\section{Discussion}

All three tests under trial have a $90 \%$ agreement with each other and with the Rose-Waaler test, although the latter comes out rather better from the comparison than the latex and bentonite tests. The proportion of equivocal results was also lowest for the Rose-Waaler test, although perhaps this is not an absolutely fair comparison because the RoseWaaler test was always set up as a full titration, whereas only a single serum dilution was used for the other tests. It might appear from these results that there is not a great deal to choose between the four tests. However, ease of performance and of reading must also be taken into account.

The bentonite test is very elegant and the agglutination of bright blue particles is an unusual and pleasing sight, although considerable difficulty was found in obtaining suspensions of constant stability. Some preparations were almost spontaneously agglutinable, giving immediate agglutination with positive sera, but shortly afterwards giving a similar appearance in negative controls. It was therefore necessary to watch the tests carefully throughout the incubation period.

The tube latex test is very simple and in the majority of cases is easy to read. Minor degrees of aggregation, however, are less easy to be sure of and are more difficult to read than agglutination in corresponding serum dilutions in the Rose-Waaler test. The latex test, and, to a lesser extent, the bentonite test, is rather sensitive to raised serum globulin, and in the presence of hyperglobulinaemia the results are less reliable.

The "RA-test" has been found to be extremely satisfactory. It is quick to do, easy to read, and requires a minimum of apparatus and no centrifuging. The reagent is rather expensive. During this survey and since its completion, we have tried out a home-made fraction II/latex reagent, which has given results which have been almost identical with those of the "RA-test," although we have not been able to achieve a reagent which remains quite so homogeneous in negative serum as does the Hyland preparation. The "RA-test" or some modification of it seems to be the test of choice where time or facilities are limited or where the small number of sera to be tested makes the Rose-Waaler test uneconomical in time and effort.
Since there is an advantage (Table IV) in using two tests and evidence that the Rose-Waaler and the fraction II tests measure different substances (see below), it seems logical to use the Rose-Waaler in combination with one of the other tests. The "RAtest " or a modification of it is the simplest and most useful of the fraction II tests which we have tried out, and we are now regularly using our modification of it in conjunction with the Rose-Waaler test.

Finally, a word must be said on the reason for divergence of results between these tests. Some differences, though probably few, are due to variations in technique and reagents; for instance, occasional rheumatoid sera only give a positive RoseWaaler test if the cells are sensitized to the very brink of agglutination (a condition not always attained), and in a very few the agglutinating property is considerably diminished by even the short period of inactivation. Similarly the fraction II tests must be at the mercy of the reagents and their sensitivity will vary according to the degree of denaturation and aggregation of the fraction II preparation used.

It is, however, probable that the fraction II and sensitized red cell tests are not indicating identical substances. Thus Heller, Jacobson, Kolodny, and Kammerer (1954) showed that absorption of a rheumatoid serum with sensitized red cells would remove the Rose-Waaler reacting property, but would leave almost unimpaired the ability to react with fraction II, whereas absorption with fraction-IIcoated cells removed both properties. Also Greenbury (1956) showed that in elution experiments the amount of protein required to cause agglutination was much less than the quantity of rheumatoid factor estimated to be in the serum by some workers, and current work (Greenbury, unpublished) is tending to confirm this. More recently Lospalluto and Ziff (1959) have by chromatographic methods separated the rheumatoid factor into fractions which differ in their relative content of fraction-II-precipitating and

TABLE V

\begin{tabular}{l|rr|c|c}
\hline & Date & $\begin{array}{c}\text { Rose- } \\
\text { Waaler } \\
\text { Titre }\end{array}$ & $\begin{array}{c}\text { Benton- } \\
\text { ite }\end{array}$ & Latex \\
\hline Patient A: & 1257 & 32 & - & - \\
Rheumatoid arthritis & 258 & 256 & - & - \\
& 458 & 64 & - & - \\
& 1158 & 256 & \pm & - \\
\hline & 159 & 256 & - & - \\
Patient B: & 958 & $<2$ & \pm & \pm \\
Rheumatoid arthritis & 1058 & $<2$ & - & + \\
\hline Patient C: & 1158 & $<2$ & - & + \\
Unresolving pneumonia & 1258 & $<2$ & - & + \\
& 1257 & $<2$ & + & - \\
\hline
\end{tabular}


sensitized-cell-agglutinating substances. Further evidence of dissociation of properties of the rheumatoid factor is found in the present series; it is not uncommon for patients to maintain over long periods a constant pattern of reaction to the different tests (see Table V.

It may of course be that in patient $\mathrm{C}$ the reaction is not with fraction II but with a fraction of the patient's own serum which has been absorbed to the bentonite

It is not uncommon, early in the disease, for either the latex or Rose-Waaler test alone to be positive, the second test not becoming positive until later on. Similarly during remission one of the tests may become negative while the other remains positive. Further work is proceeding on the quantitative aspects of the sensitized red cell and fraction-IIcombining properties of the rheumatoid factor.

It is worth noting how comparatively unreliable is the diagnosis given on laboratory request forms. This is well shown in Table III, where the results from the Rheumatism Research Centre and from other sources are compared. It is clear that laboratory request forms are not a suitable basis upon which to form conclusions concerning the accuracy of laboratory tests, at least where diagnosis of the disease in question is not straightforward.

I wish to thank Dr. A. G. S. Hill, Director of the Oxford Regional Rheumatism Research Centre, for clinical information concerning his patients, and, together with Dr. Hill, Dr. M. S. Good, and Dr. R. Spalding Smith, for their permission to use some of the material collected for our joint publication on the clinical significance of the Rose-Waaler test. I wish to thank also Dr. P. Armitage, of the Statistical Research Unit of the M.R.C., for his statistical help and advice.

The RA-test reagent was kindly supplied free of charge by Messrs. Hyland Laboratories, Los Angeles, California.

\section{REFERENCES}

Bozicevich, J., Bunim, J. J., Freund, J., and Ward, S. B. (1958) Proc. Soc. exp. Biol. (N.Y.), 87, 180.

Franklin, E. C., Holman, H. R., Müller-Eberhard, H. J., and Kunkel, H. G. (1957). J. exp. Med., 105, 425.

Greenbury, C. L. (1956). Lancet, 2, 644.

(1957). Broadsheet No. 18 (New Series) of the Association of Clinical Pathologists.

Heller, G., Jacobson, A. S., Kolodny, M. H., and Kammerer, W. H. (1954). J. Immunol., 72, 66.

Lospalluto, J., and Ziff, M. (1959). J. exp. Med., 110, 169.

Murray, J. (1944). Lancet, $2,594$.

Singer, J. M., and Plotz, C. M. (1956). Amer. J. Med., $21,888$. 